\title{
MICROPROPAGATION OF WILD CHERRY (Prunus avium L.) FROM A CLONAL SEED ORCHARD
}

\author{
MIKRORAZMNOŽAVANJE DIVLJE TREŠNJE (Prunus avium L.) \\ IZ KLONSKE SJEMENSKE PLANTAŽE
}

\author{
Olivera TANČEVA CRMARIĆ ${ }^{1}$, Davorin KAJBA²
}

\begin{abstract}
A total of 24 genotypes (selected adult plus trees) were introduced from a clonal seed orchard of wild cherry (Prunus avium L.) in the process of in vitro production. The possibilities of optimizing routine micropropagation methods of the clones at all stages were explored. Several techniques were established that allow the introduction of the initial culture throughout the year. A total of 23 clones were successfully introduced over the four seasons. Clone L3 was not successfully disinfected and was not introduced into the initial culture. The specific composition of culture media and the unique combination of growth regulators were determined in all in vitro production stages, leading to the growth of high-quality plants with very good survival during the acclimatization process. BAP- $1.0 \mathrm{mg} / \mathrm{L}$, Kinetin- $0.5 \mathrm{mg} / \mathrm{L}$ and IAA- $0.5 \mathrm{mg} / \mathrm{L}$ were used for micropropagation, which resulted in the multiplication rate of 3-9 with shoot heights from 1.5 to $3.0 \mathrm{~cm}$. Rooting of microcuttings was achieved by a combination of IAA- $2.0 \mathrm{mg} / \mathrm{L}, \mathrm{IBA}-2.0 \mathrm{mg} / \mathrm{L}$ with the addition of GA3- $-0.2 \mathrm{mg} / \mathrm{L}$. The rooted plantlets of wild cherry developed normal internodes and leaf blades, and the roots were well formed with 3 to 7 roots per plant, whose length increased the longer they remained in the culture medium. The micropropagated selected plus trees manifested strong apical dominance and the majority of the young plants reached a height of over one meter in the period of seven months.
\end{abstract}

KEY WORDS: in vitro propagation, selected plus trees, clonal seed orchard, wild cherry

\section{INTRODUCTION}

\section{UVOD}

Improvement of wild cherry (Prunus avium L., family Rosaceae), with conventional propagation methods could be a very slow process impeded by the difficulty of finding regular and sufficient quantities of natural seed. Although the establishment of clonal seed orchards ensures a more regular yield of good quality seed, it does not eliminate the dependence on weather conditions which affect blossoming and seed yield, nor does it solve difficulties related to seed germination. Certain biotechnological in vitro methods accelerate the process and ensure genetic stability. Microclonal propagation of rejuvenated individuals, derived from adult elite genotypes is the fastest and the best method of wild cherry improvement. Process optimization facilitates the problems and reduces production costs. Both additive and non-additive components of genetic variability are thus preserved. Good quality plantlets with known characteristics that are obtained over a short period could be used not only for the establishment and replacement of clonal seed

\footnotetext{
1 Dr. sc. Olivera Tančeva Crmarić, Vitroplant Ltd., Solin, Croatia

${ }_{2}^{2}$ Prof. dr. sc. Davorin Kajba, Faculty of Forestry University of Zagreb, Svetošimunska 25, 10002 Zagreb, Croatia, e-mail: davorin.kajba@zg.t-com.hr
} 
orchards, but also for direct afforestation of certain areas or for reforestation forest stands with elite genotypes, as well as for further improvement.

A number of investigations into in vitro propagation of wild cherry have been carried out to date (Druart et al. 1981; Pevalek-Kozlina and Jelaska 1987; Cornu 1990; Hammerschlag and Scorza 1991; Gruselle et al. 1995; Ružić et al. 2003; Szczygieł and Wojda 2008) - primarily because of the high timber value of this species. In the nature, the existence of wild cherry types of up to 50 individuals is exceptionally rare and occurs only in several cases. The in situ conservation of such genotypes may be difficult if they are privately owned or if they are overmature, since the tree trunk progressively begins to decay after 80 years of age. The ex situ conservation in clonal seed orchards makes it possible to conserve either the unmodified genetic constitution or genetic constitution with minimal possibility of change through mutations, selections, drift or gene contamination of plant material. The introduction of new conservation methods of wild cherry genetic resources, such as in vitro vegetative propagation or cryopreservation, would increase the possibility of controlling genetic stability, especially if molecular characterization of each clone is carried out.

Meristem reproduction of selected elite trees of wild cherry was set up by Ivanička and Pretova (1986) and Douglas (1999). In Croatia, primary research into microclonal propagation of wild cherry for the purpose of obtaining rapid in vitro micropropagation was conducted by Pevalek-Kozlina and Jelaska (1987). The experiment included several differently-aged genotypes.

Variability of elite wild cherry trees in combination with in vitro mass production was studied by Hammatt and Grant (1997) and Durkovič (2006). An annual height increment of 1.8-2.0 $\mathrm{m}$ of these wild cherry seedlings was recorded. The in vitro culture of wild cherry with meristem or shoot explants is performed by organogenesis through three stages of the process. These include differentiation of the explants into the leaf rosettes, micropropagation and shoot elongation, as well as their rooting, similarly to other woody species, and finally their outplanting.

In Croatia, a clonal seed orchard of wild cherry with 27 selected clones was established in Kutina (Kajba et al. 2006, 2012). The ramets of this orchard provided the starting, planting stock for the research done in this work. To introduce the selected material into the in vitro procedure and mass vegetative propagation, twigs with formed buds in the dormant stage were used, as well as those in the growth stage.

Drawing on previous research into micropropagation of cultivated and wild cherry, the possibility of optimizing the routine of tissue culture methods for clone propagation (plus trees) of wild cherry at all the stages was attempted, starting from the initial culture, micropropagation, elongation, rooting and acclimatisation and in vivo hardening of the plants to the stage of commercial plants.

\section{MATERIALS AND METHODS MATERIJAL I METODE RADA}

The grown shoots collected from grafted plants during different seasons of the year (July 2007-June 2008) provided the initial material. Plant material consisted of axillary and terminal buds of a total of 24 clones of wild cherry from the clonal seed orchard in Kutina. The following clones were used in experiment: G1, KP5 (summer); ĐU2, K5, L1, R1 (autumn); ĐU1, G2, K1, K3, KC1, KC2, KP2, KP3, L4, N3, NB1, PŽ, R2 (winter); and K3, L5, L6, N1 (spring). Clone $\mathrm{K} 3$ was introduced in the experiment twice (winter; spring). Clone L3 was not successfully disinfected and was not introduced into the initial culture.

Twigs that were used to isolate axillary buds were excised in different developmental stages of plant material during all the four seasons of the year. The material was disinfected as described in Table 1. Different methods have been used for

Table 1 Disinfection of plant material Tablica 1 Dezinfekcija biljnog materijala

\begin{tabular}{|c|c|c|c|c|}
\hline & $\begin{array}{l}\text { Summer } \\
\text { Ljeto }\end{array}$ & $\begin{array}{l}\text { Autumn } \\
\text { Jesen }\end{array}$ & $\begin{array}{l}\text { Winter } \\
\text { Zima }\end{array}$ & $\begin{array}{l}\text { Spring } \\
\text { Proljeće }\end{array}$ \\
\hline $\begin{array}{l}\text { Running water supplemented with Tween } 20 \\
\text { Tekuća voda s dodatkom Tween } 20\end{array}$ & $10^{\prime}$ & $15^{\prime}$ & $30^{\prime}$ & $10^{\prime}$ \\
\hline $\begin{array}{l}\text { Sterile water supplemented with ascorbic } \\
\text { acid and antibiotics } \\
\text { Sterilna voda } s \text { dodatkom askorbinske } \\
\text { kiseline i antibiotika }\end{array}$ & $30-120^{\prime}$ & $60^{\prime}$ & $60-120^{\prime}$ & $10-30^{\prime}$ \\
\hline $\begin{array}{l}\text { Ethyl alcohol } 70 \% \\
\text { Etilni alkohol } 70 \%\end{array}$ & $20^{\prime \prime}$ & $30^{\prime \prime}$ & $30^{\prime \prime}$ & Quick deep \\
\hline $\begin{array}{l}\text { Domestos and Izosan solution } \\
\text { Otopina Domestosa i Izosana }\end{array}$ & $\begin{array}{l}0.8-1.5 \% \\
8^{\prime}\end{array}$ & $\begin{array}{l}1.2 \% \\
15^{\prime}\end{array}$ & $\begin{array}{c}1.0-2.0 \% \\
15-20^{\prime}\end{array}$ & $\begin{array}{l}0.7-0.9 \% \\
8^{\prime}\end{array}$ \\
\hline $\begin{array}{l}\text { Washing with sterile water } \\
\text { Ispiranje sterilnom vodom }\end{array}$ & $3 \times 5^{\prime}$ & $3 \times 5^{\prime}$ & $3 \times 10^{\prime}$ & $2 \times 3^{\prime}$ \\
\hline
\end{tabular}


plant disinfection, and the main disinfecting solutions used in this study were: Tween 20, Domestos and Izosan G chlorine solutions, $70 \%$ ethyl alcohol, and sterile water supplemented with ascorbic acid and antibiotics. In this research, hypochlorite-based solutions Domestos and Izosan G were used for reasons of their lesser toxicity during handling.

After disinfection, bud leaflets were unfolded under a binocular loupe and were severed from the nodals to a size of approximately $2 \mathrm{~mm}$, which comprises the meristem and the first pair of leaflets. Ten explants from each cultivar were set up, and successful disinfection was expected to yield $50 \%$, or five pure initial cultures. The clones were gradually introduced into the initial culture. A total of 23 clones were successfully introduced over the four seasons.

The culture medium for the establishment of the initial culture of axillary and terminal meristems of wild cherry consisted of MS medium (Murashige and Skoog 1962), supplemented with: potassium chloride, potassium sulphate, biotin, riboflavin, folic acid, calcium pantothenate and glycine (Table 2). Myo-inositol was not included, and macroelements were in half-strength concentrations.

The universal culture medium for axillary bud multiplication of all the 23 clones of wild cherry consisted of our own combination of MS (Murashige and Skoog 1962), LM (Lloyd and McCown 1981), WPM and OM (Rugini 1984) basal media, supplemented with Staba modified vitamins. Compositions of culture mediums for in vitro production of wild cherry per stage, as well as the plant hormones used in different stages of in vitro production are presented in tables 2 and 3.

Different concentrations of growth regulators were tested and the formation of new shoots, multiplication rates and duration were monitored. Five plantlets from each clone were set up in each concentration and were replicated twice in order to reliably determine the effect of growth regulators.

All mediums were supplemented with $6.5 \mathrm{~g} / \mathrm{L}$ of agar, and saccharose as follows: initial culture, $25 \mathrm{~g} / \mathrm{L}$; axillary shoot multiplication, $30 \mathrm{~g} / \mathrm{L}$; shoot elongation $30 \mathrm{~g} / \mathrm{L}$; rooting of microplantlets, $20 \mathrm{~g} / \mathrm{L}$. Culture mediums used in micropropagation of wild cherry were prepared by dissolving all media components in a flask of distilled water placed on stirring/hot plate. All media were adjusted to $\mathrm{pH} 5.8$ with $\mathrm{NaOH}$, and autoclaved at $120^{\circ} \mathrm{C}$ for $30 \mathrm{~min}$.

The acclimatization was carried out under greenhouse conditions where temperature, light, and air humidity were adequate for a gradual hardening of plantlets. The plants were planted into a Klasman growing medium placed in $30 \times 50$ polystyrene liner trays (containers) with 42 planting holes, at a temperature at the root base from 20 to $24^{\circ} \mathrm{C}$, relative humidity of 70 to $90 \%$ and daily light of 5,00010,000 lux. Artificial light with $400 \mathrm{~W}$ mercury vapour lamps was used during short days. For further plant culti-
Table 2 Composition of culture mediums for in vitro production of wild cherry per stage

Tablica 2 Sastav hranidbenih podloga za in vitro proizvodnju divlje trešnje po fazama

\begin{tabular}{|c|c|c|c|c|}
\hline 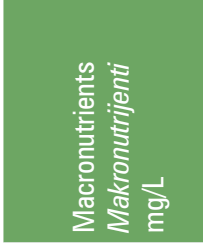 & 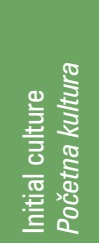 & 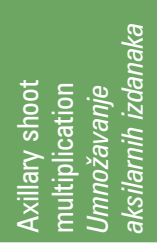 & 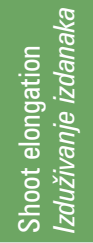 & 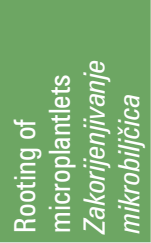 \\
\hline $\mathrm{KNO}_{3}$ & 950 & 190 & 190 & 950 \\
\hline $\mathrm{Ca}\left(\mathrm{NO}_{3}\right) \cdot 4 \mathrm{H}_{2} \mathrm{O}$ & - & 600 & 600 & - \\
\hline $\mathrm{NH}_{4} \mathrm{NO}_{3}$ & 825 & 400 & 400 & 825 \\
\hline $\mathrm{NH}_{4} \mathrm{H}_{2} \mathrm{PO}_{4}$ & - & 100 & 100 & - \\
\hline $\mathrm{KH}_{2} \mathrm{PO}_{4}$ & 85 & 170 & 170 & 85 \\
\hline $\mathrm{KCl}$ & 100 & 100 & - & - \\
\hline $\mathrm{K}_{2} \mathrm{SO}_{4}$ & 445 & 330 & - & - \\
\hline $\mathrm{CaCl} 2 \cdot 2 \mathrm{H} 2 \mathrm{O}$ & 220 & 96 & 96 & 220 \\
\hline $\mathrm{MgSO}_{4} \cdot 7 \mathrm{H}_{2} \mathrm{O}$ & 185 & 370 & 370 & 370 \\
\hline \multicolumn{5}{|l|}{$\begin{array}{l}\text { Micronutrients } \\
\text { Mikronutrijenti } \\
\mathrm{mg} / \mathrm{L}\end{array}$} \\
\hline $\mathrm{MnSO}_{4} \cdot 4 \mathrm{H}_{2} \mathrm{O}$ & 22.3 & 22.3 & 22.3 & 22.3 \\
\hline $\mathrm{ZnSO}_{4} \cdot 7 \mathrm{H}_{2} \mathrm{O}$ & 8.6 & 8.6 & 8.6 & 8.6 \\
\hline $\mathrm{H}_{3} \mathrm{BO}_{3}$ & 6.2 & 6.2 & 6.2 & 6.2 \\
\hline $\mathrm{KI}$ & 0.83 & 0.83 & 0.83 & 0.83 \\
\hline $\mathrm{CuSO}_{4} \cdot 5 \mathrm{H}_{2} \mathrm{O}$ & 0.025 & 0.025 & 0.025 & 0.025 \\
\hline $\mathrm{Na}_{2} \mathrm{MoO}_{4} \cdot 2 \mathrm{H}_{2} \mathrm{O}$ & 0.25 & 0.25 & 0.25 & 0.25 \\
\hline $\mathrm{CoCl}_{2} \cdot 6 \mathrm{H}_{2} \mathrm{O}$ & 0.025 & 0.025 & 0.025 & 0.025 \\
\hline $\mathrm{FeSO}_{4} \cdot 7 \mathrm{H}_{2} \mathrm{O}$ & 27.8 & 27.8 & 27.8 & 27.8 \\
\hline $\mathrm{Na}_{2}$ EDTA & 37.3 & 37.3 & 37.3 & 37.3 \\
\hline \multicolumn{5}{|c|}{$\begin{array}{l}\text { Vitamins and other supplements } \\
\text { Vitamini i ostali dodatci } \\
\mathrm{mg} / \mathrm{L}\end{array}$} \\
\hline Adenin sulphate & - & 50 & - & - \\
\hline L-tyrosine & - & 50 & - & - \\
\hline Myo-inositol & - & 100 & - & 100 \\
\hline Thiamine $\mathrm{HCl}$ & 0.5 & 1.0 & 2.0 & 2.0 \\
\hline Pyridoxine $\mathrm{HCl}$ & 0.5 & 2.0 & - & - \\
\hline Nicotinic acid & 0.5 & 2.0 & 1.0 & 1.0 \\
\hline Biotine & 0.1 & 1 & - & 0.1 \\
\hline Riboflavin & 0.1 & 0.5 & - & 0.1 \\
\hline Folic acid & 0.2 & 0.2 & - & 0.2 \\
\hline Ca Pantothenate & 2.0 & - & - & - \\
\hline Glycine & 2.0 & 4.0 & 4.0 & 4.0 \\
\hline
\end{tabular}

vation and growth, the average temperature was about $18^{\circ} \mathrm{C}$ in winter and $25-28^{\circ} \mathrm{C}$ in summer, with relative humidity of about $70 \%$.

\section{RESULTS}

REZULTATI

The use of the cytokinin Kinetin to stimulate axillary branching in the multiplication phase had a positive effect on the formation of morphologically regular, firm, exceptio- 
nally vigour plants with nicely formed leaf blades, without additional callus formations and without the occurrence of vitrified plants. The plants were 1.5 to $3 \mathrm{~cm}$ tall and the internodes were adequately arranged. The multiplication rate was 1 at a concentration of 1 and $2 \mathrm{mg} / \mathrm{L}$, whereas it amounted to 2.5 at a concentration of $4 \mathrm{mg} / \mathrm{L}$. The formed plants achieved $100 \%$ in vitro rooting later on. These kinetin concentrations did not interrupt apical dominance and did not stimulate the formation of axillary shoots regardless of the duration of multiplication. The plantlets in the culture medium experienced the most intensive growth in the first 14 days of subcultivation, but subsequently started to loos their juvenile appearance.The application of the cytokinin BAP in the in vitro multiplication phase of wild cherry resulted in the formation of shoot clusters with several axillary shoots, depending on the used concentration and on clonal origin. Concentrations of $0.5 \mathrm{mg} / \mathrm{L}$ BAP resulted in morphologically regular shoot clusters with 2-3 axillary shoots, $1.5-2.0 \mathrm{~cm}$ tall, with no callus at the base, without any vitrification and with regularly formed internodes and leaf blades. A concentration of $1.0 \mathrm{mg} / \mathrm{L}$ BAP proved to be the most efficient. Properly shaped clusters with visible interruption of apical dominance and with new axillary shoots. The internodes were of normal appearance, the leaf blades were of exemplary size, and the colour was natural green with very little formation of unidentified callus at the base of the shoot clusters. The shoot clusters retained their juvenile appearance up to the $27^{\text {th }}$ day of subcultivation, when they were transferred to fresh culture medium. The highest multiplication rate was recorded at a concentration of $1.5 \mathrm{mg} / \mathrm{L}$ BAP but with a lower microplant quality. The clusters turned yellowish in colour, the leaves and stems became brittle and the internodes were short. The newly formed axillary shoots ranged between 0.7 and $1.2 \mathrm{~cm}$ in height after 28 days of subcultivation, and occurred in all the axiles. A small callus growth was noticed at the base of the clusters. The shoots were fragile and broke during the excision process. A concentration of $2 \mathrm{mg} / \mathrm{L}$ BAP led to decreased multiplication and increased callus formation at the base of the clusters. The leaves were irregularly developed. Older leaves had partially increased and disproportionate leaf blades in relation to the shoots. The axillary shoots in the leaf axils were shorter and, although rare, the tips of the newly formed shoots were vitrified as a result of high BAP concentrations. The use of the cytokinin $2 \mathrm{iP}$ in concentrations of 5 and $10 \mathrm{mg} / \mathrm{L}$ did not stimulate multiplication, and concentration of $5 \mathrm{mg} / \mathrm{L}$ did not initiate the growth of the cultured explants. The plants remained undeveloped and had small yellowish tips. At a concentration of $10 \mathrm{mg} / \mathrm{L} 2 \mathrm{iP}$ the plants grew well and retained their green colour, but there was no multiplication or callus formation.

Drawing on the results of favourable effects of kinetin on plant height growth and the role of BAP in interrupting apical dominance and forming numerous axillary shoots, BAP and kinetin were combined in the culture medium with the purpose of establishing a production model for in vitro mass propagation of wild cherry. A BAP concentration of 1.0 $\mathrm{mg} / \mathrm{L}$ was used, which yielded the best results when supplemented with $0.5 \mathrm{mg} / \mathrm{L}$ of kinetin. A combination of different concentrations of growth regulators stressed their importance in the stage of wild cherry multiplication. In spite of identical composition of culture media in all the experiments and of clonal origin of the explants, accurately determined and very large differences occurred in the morphological appearance of the shoot clusters, in the colour, firmness/juvenility of the material, and in the number of newly formed shoots. This selection eventually resulted in shoot clusters of natural appearance, with regularly formed internodes, a multiplication rate of 3-9 in dependence of clonal origin, and the duration of subcultivation of 22 to 27 days. The auxin IAA in a concentration of $0.5 \mathrm{mg} / \mathrm{L}$ was present in the culture media for wild cherry multiplication in all the tests.

The composition of all culture media satisfied the requirements of young plants at all stages. Regardless of their clonal origin, the plants were morphologically well developed and luscious, and vitrification occurred only as a result of high BAP concentrations. The selected culture media and the selected combination of growth regulators in the multiplication stage proved efficient for all the 23 clones of wild cherry. For mass production of only one clone or a selected clone group, slight modifications of cytokinin concentrations produce maximal multiplication. Namely, shoot clusters

Table 3 Plant hormones used in different stages of in vitro production of wild cherry Tablica 3 Korišteni regulatori rasta za in vitro proizvodnju divlje trešnje

$\begin{array}{ccccc}\begin{array}{c}\text { Plant hormones } \\ \text { Biljni hormoni } \\ \text { mg/L }\end{array} & \begin{array}{c}\text { Initial culture } \\ \text { Početna kultura }\end{array} & \begin{array}{c}\text { Axillary shoot multiplication } \\ \text { Umnožavanje } \\ \text { aksilarnih izdanaka }\end{array} & \begin{array}{c}\text { Shoot elongation } \\ \text { Izduživanje izdanaka }\end{array} & \begin{array}{c}\text { Rooting of microplantlets } \\ \text { Zakorijenjivanje } \\ \text { mikrobiljčica }\end{array} \\ \text { IAA } & 1.0 & 0.5 & - & - \\ \text { IBA } & - & - & - & 2.0 \\ \text { BAP } & 0.4 & 0.5-2.0 & 0.5 & - \\ \text { Kinetin } & 0.2 & 1.0-4.0 & 0.2 & - \\ \text { GA3 } & - & - & - & - \\ \text { LiP } & - & 5 \text { and } 10 & & -\end{array}$




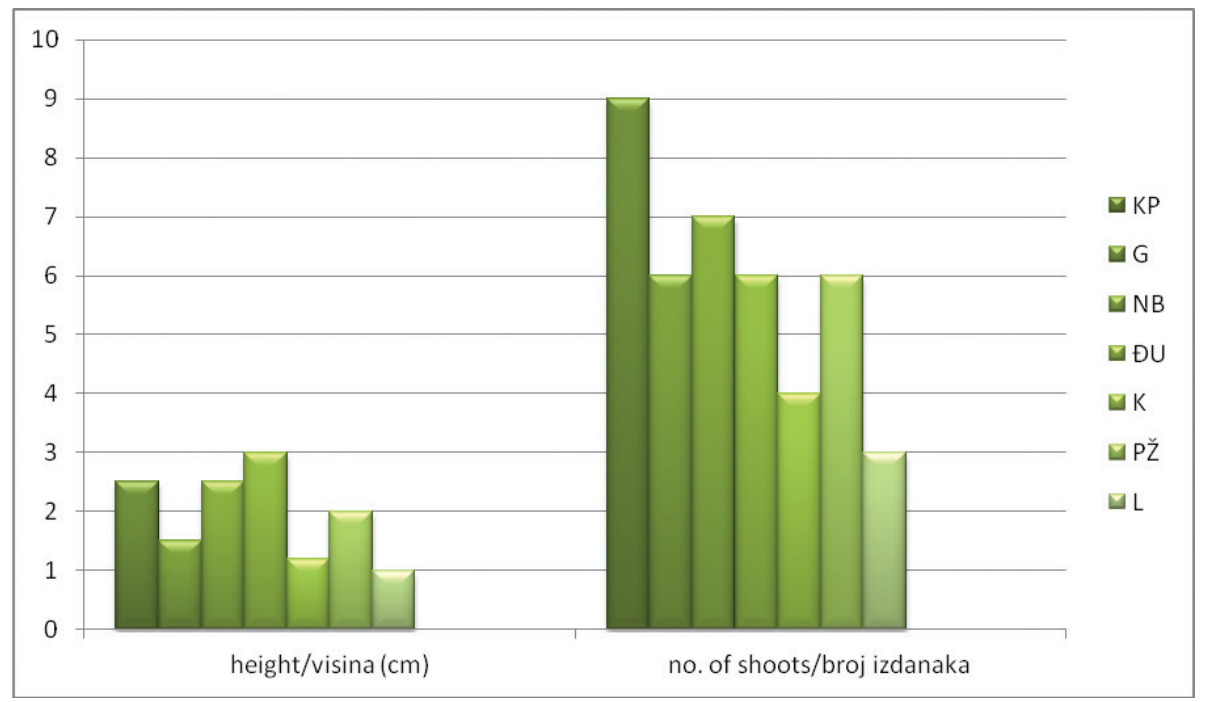

Figure 1. Height of newly formed axillary shoots per shoot cluster multiplication according to clonal origin during in vitro multiplication stage of wild cherry

Slika 1. Visina novostvorenih aksilarnih izdanaka po nakupinama i visinama za vrijeme multiplikacije divlje trešnje in vitro

manifested different behaviour patterns in dependence of certain geographic/regional clone origin. After 27 days of subcultivation on a shoot multiplication medium, there were differences in height, size of internodes and leaf blades, as well as in multiplication rates, as shown in Figure 1.

No correlation was established between the heights of formed clone microplants during multiplication with the heights of the same clones preserved in situ.

Shoot clusters obtained from wild cherry multiplication, especially clones which did not reach $1.5 \mathrm{~cm}$ in height, were subcultivated on the elongation medium, where an increase of shoots in the shoot clusters was observed. After 20 days, microcutings were excised and transferred to the rooting medium. The elongation phase is exceptionally important because tiny rooted plantlets cannot acclimatise successfully, thus incurring severe losses.

In this research, subjecting the shoot clusters to dark periods proved less efficient because a very low percent of microplantlets started growing. At the same time, shoot quality decreased as the shoot lost a healthy green colour. Shoots that were elongated in the dark abruptly increased their internodes and became thinner, while the leaf blades remained small and pale. It is very likely that dark periods in the elongation stage could result in the deterioration of shoot tips. This method of plant elongation yields potted microplants of exceptionally uneven appearance.

In order to overcome these problems, the shoot clusters were transferred to a culture medium supplemented with Kinetin $0.5 \mathrm{mg} / \mathrm{L}$ and GA3 0.2 mg/L for 20 days, despite the fact that one more elongation subcultivation raised the cost of the process. This resulted in uniformly elongated shoots with elongated internodes. The leaves retained their green colour, the shoots did not thin out and no tips were degenerated. These microcuttings rooted more rapidly and achieved a very high survival percentage in the acclimatization stage.

It is important to obtain good quality plantlets with sturdy leaves and with root systems capable of performing their role in the acclimatisation stage. In this research, the selected medium for in vitro rooting of wild cherry and a combination of growth regulators IAA and IBA in the in vitro condition proved successful.

The plantlets obtained by micropropagation were rooted during April and May 2008. The quantities ranged from 50 to 150 plants, depending on the clone and the time of introduction into the initial culture. Owing to the fact that only well formed plants of good quality were used for rooting, the rooting success was above $90 \%$.

After 14 days, wild cherry plantlets derived from the 23 studied clones were successfully rooted and continued growing and developing their roots. In the in vitro rooting stage they grew up to $5 \mathrm{~cm}$ in height. The rooted plantlets of wild cherry developed normal internodes and leaf blades, and the roots were well formed. There were 3 to 7 roots per plantlet, whose length increased the longer they remained in the culture medium.

After 30 days, the plantlets were transferred from acclimatisation to container pots in the greenhouse, where they remain on the benches until they reach a height of $10 \mathrm{~cm}$. The conditions in the greenhouse are partially controlled and include watering and nutrition, heating and cooling, as well as meticulous plant material protection. Survival ranged from 70 to $90 \%$ after acclimatisation, depending on the clone variability. 


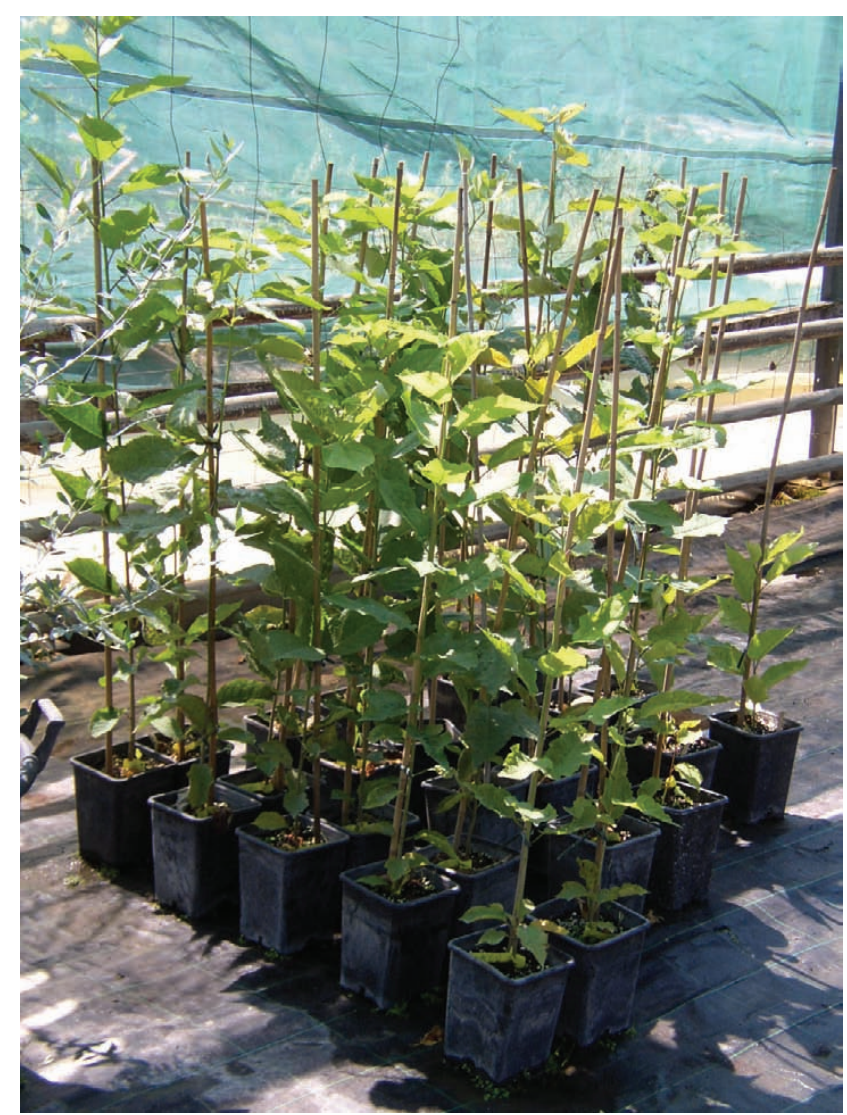

Figure 2 Seven months old micropropagated plants of Prunus avium L. Slika 2 Mikrorazmnožene biljke Prunus avium L.u dobi od sedam mjeseci

The plant material is later stored in open sites where, protected with a net from weather conditions, it remains until delivery. The material can be delivered in the growth or dormant stage. The material is characterized by excellent health (regularly controlled by the Plant Protection Institute) and by well developed roots.

A certain number of wild cherry plants, one plant from each clone produced in vitro and acclimatized to in vivo conditions during the winter of 2009/2010 were pot planted in the spring and monitored. Intensive growth was recorded during spring, and most of the young plants reached a height of over 1 meter (Figure 2).

\section{DISCUSSION}

RASPRAVA

The disinfection procedure was established for all the 24 clones of wild cherry in all the four seasons of the year. Research was initiated in July 2007. To isolate the explants, 30 $\mathrm{cm}$ long twigs were collected from the ramets with vegetative axillary buds in the dormant stage. A total of 23 clones were successfully introduced over the four seasons. Clone L3 was not successfully disinfected and was not introduced into the initial culture.
In several of the published papers on micropropagation of wild cherry (Harrington et al. 1994; Pevalek et al. 1994; Hammatt and Grant 1997; Hammatt 1999; Osterc et al. 2004; Durković 2006; Mansseri-Lamrioui et al. 2009), the initial explants were established by means of axillary or terminal buds. Initial explants are generally established in the initial culture during active growth of the mother plant in early spring. Fidanci et al. (2008) reports on the introduction of explants from the end of April to the beginning of June, since later collection of explants leads to a high degree of contamination, browning of clumps and reduced growth accompanied by a low multiplication rate. The introduction of woody plant material of wild cherry into the initial micropropagation culture may also present a problem due to overmature ortets or the infected initial material growing in natural forest habitats.

The need to produce wild cherry in vitro may also occur during different seasons, particularly if a certain genotype should be preserved. For this reason, it is of utmost importance to disinfect the initial material of wild cherry throughout the year.

According to the results of different research (Pevalek-Kozlina and Jelaska 1987; Sedlak et al. 2008; Scaltsoyiannes et al. 2009), the best time of collection and establishment is at the beginning of vegetation and intensive growth in the spring. Such material is healthy and is hardly ever contaminated with pathogens or external agents. The research resulted in a high survival rate of the initial explants (70-80\%), and all the clones were introduced into the initial culture.

In vitro research with woody plant material frequently reports on the use of mercury chloride for disinfection. To disinfect axillary buds from 10-year-old material, Sedlak et al. (2008) used $0.15 \%$ solution of mercury chloride for one minute, while Mansseri-Lamrioui et al. (2009) used $2.5 \mathrm{~g} / \mathrm{L}$ for 20 minutes. In the works of Szczygieł and Wojda (2008), disinfection with calcium hypochlorite was unsuccessful, but disinfection with $0.1 \%$ mercury chloride was successful. Pevalek-Kozlina and Jelaska (1987) and Scaltsoyiannes et al. (2009) successfully disinfected wild cherry with mercury chloride, applied over a shorter time interval and in lower concentrations. Apart from hypochlorite solutions and mercury chloride, some newer disinfectants have been used more recently, such as DICA (dichloroisocyanuric acid sodium salt) in combination with $70 \%$ alcohol (Osterch et al. 2004).

The success of micropropagation through in vitro cultures depends on a number of factors. The mineral and hormonal composition of the culture medium, as well as the age of initial explants is of high importance (Chikh 2000). Different mineral systems are used for micropropagation of the selected species, and formulations vary greatly depending on the cultivar, genotype or source of plant material 
(Rifaud and Cornu 1981; Tricoli et al. 1985; Druart 1992; Dolcet-Sanjuan et al. 2004).

There have been various studies on the effect of different compositions of culture media for in vitro production of root stock for grafting wild cherry and cultivated cherry. Culture media MS, $1 \frac{1}{2}$ MS, QL (Quorin and Lepoivre 1977), $1 / 2$ QL, Knop, Heller, commonly fortified with agar $7 \mathrm{~g} / \mathrm{L}$ and pH 5.8 are cited in the works of: Ivanička and Pretova (1986), Pevalek-Kozlina and Jelaska (1987), Hammatt (1999), Fotopoulos and Sotiropoulos (2005), Sedlak et al. (2008), Scaltsoyiannes et al. (2009) and Tančeva Crmarić (2011). Drawing on different experience, including our own, and on the results from literature, new culture media were formed for this research for all the stages of in vitro cultivation of wild cherry.

Protocols developed for micropropagation of wild cherry and other species of the genus Prunus (Yang and Schmidt 1994; Al-Sabbagh et al. 1999; Pruski et al. 2000; Ruzič et al. 2003; Ruzič and Vujovič 2008) are not broadly used; rather, the protocols are determined by the genotype. In this research, the selected culture medium and a combination of growth regulators resulted in acceptable multiplication of morphologically well formed plants, with no vitrification, for all the 23 genotypes of wild cherry under study.

Although past literature mentions only one cytokinin for multiplication and only one auxin for rooting, in this research the quality of multiplied shoots was improved with a combination of cytokinin with the auxin IAA through all the subcultures of multiplications, which had a favourable effect on plant rooting later on. The use of BAP in the multiplication process of both wild and cultivated cherry is common. Concentrations range from $0.2 \mathrm{mg} / \mathrm{L}$ to $2.0 \mathrm{mg} / \mathrm{L}$ (Garin et al. 1997; Hammatt and Grant 1997; Grant and Hammatt 1999, 2000; Fidanci et al. 2008; Sedlak et al. 2008; Scaltsoyiannes et al. 2009).

The following cytokinins have so far been used in wild cherry multiplication: BAP, kinetin, Thidiazuron. However, there are no data on the use of 2iP. For this reason, multiplication with two concentrations was attempted in this work in order to study its effects. This cytokinin did not prove suitable for wild cherry multiplication because it did not stimulate the formation of axillary shoots, unlike black chokeberry (Aronia melanocarpa L.), where it proved excellent. In view of the above, experiments with concentrations above $10 \mathrm{mg} / \mathrm{L}$ are required since the use of $2 \mathrm{iP}$ in the multiplication of black chokeberry resulted in the development of tall plants (unpublished data), taller than $4 \mathrm{~cm}$, which is very important in the rooting stage, and later on for survival in the acclimatisation stage. Numerous investigations of in vitro plant production involved the use of antibiotics in the process for the purpose of eliminating bacterial contamination and preserving healthy planting stock. Sedlak et al. (2008) reports on the application of the antibiotic Cefotaxime $200 \mathrm{mg} / \mathrm{L}$ to overcome bacterial contamination during multiplication. In this research, $3 \mathrm{mg} / \mathrm{L}$ of a broadspectrum antibiotic Rifampicin was successfully used in the multiplication phase and no bacterial contamination was recorded.

Zilkah et al. (1992) supplemented the medium with GA3 for elongation. In order to achieve elongation, Scaltsoyiannes et al. (2009) put a red cover over the pots with microplantlets during the multiplication stage.

In vitro rooting is estimated to account for up to $75 \%$ of production costs in laboratories (Debergh and Maene 1981). For this reason, a number of authors used in vivo rooting or concentrated on obtaining tall plants of normal appearance, whose survival was high during the acclimatisation stage.

An increase in sugar concentrations in the culture medium led to more resistant plants capable of better adaptation to the transfer since an increase in plant size and total dry matter content was confirmed (Wainwright and Scarce 1989). However, there are opposite views which argue that sugar quantities should be lowered if $\mathrm{CO}_{2}$ sources and photon flux density are increased (Kozai and Iwanami 1988). In order to obtain plants with closed stomata, tests aimed at reducing humidity in apple microplantlets were carried out. The procedure involved the use of desiccants in the elongation and rooting stage, mechanical cooling of glass walls or opening the tops of glass containers (Brainerd and Fuchigami 1981).

There were also experiments involving the addition of growth retardants to reduce the leaf area. The most commonly used retardant for apple was paclobutrazol (Swietlik and Miller 1983). In their experiments, Wardle et al. (1983) added abscisic acid to force plants to lose their leaves and form new leaves in the acclimatisation stage.

Plant acclimatisation is the key step to successful production of in vitro plants. Although extensive research has been dedicated to in vitro production, efforts in overcoming production difficulties in the laboratory will be futile if the problem of transferring the plants from in vitro to in vivo conditions is not solved. Plant acclimatisation is always the bottleneck of this technology (Hazarika 2003). In order to sustain successful plant survival in the acclimatisation substrate, adequate conditions should be ensured, including air and substrate moisture by means of fog and mist irrigation systems and substrate temperature by means of winter heating and summer cooling systems. Additional light should also be provided during short winter days, as well as shade during summer months when light intensity is very high. Moreover, plant nutrition and protection during the entire acclimatisation period is of outstanding importance. 
Research into in vitro cultures of noble forest tree species has since the very beginning been aimed at exploring the possibility of clonal propagation of mature, elite genotypes and the production of plants with their own roots. Rooting and acclimatisation stages in the species Juglans nigra L., Quercus rubra L. and Castanea dentata (Marsh.) Borkh. are reported to be the limiting factors of micropropagation production (Pijut et al. 2007).

The micropropagated individuals obtained in this research have characteristics that are comparable to both German (Vornam and Gebhardt 1999) micropropagated plants and French clones presented by Santi et al. (1998). Compared to the plants obtained from seed, the in vitro plants showed an improved root system with more than three roots per plant. Their quality can be corrected with in vitro treatments (Gebhardt 1985; Meier-Dinkel 1986).

\section{CONCLUSIONS ZAKLJUČCI}

Selected adult plus trees of wild cherry from a clonal seed orchard were successfully propagated in vitro and optimize routine micropropagation methods at all stages were explored. Several techniques were established that allow the introduction of the initial culture throughout the year. The specific composition of culture media and the unique combination of growth regulators were determined in all in $v i$ tro production stages, leading to the growth of high-quality plants with very good survival during the acclimatization process. The rooted plantlets of wild cherry developed normal internodes and leaf blades, and the roots were well formed with 3 to 7 roots per plant, whose length increased the longer they remained in the culture medium. The micropropagated selected plus trees manifested strong apical dominance and the majority of the young plants reached a height of over one metre in the period of seven months.

\section{REFERENCES}

\section{LITERATURA}

- Al-Sabbagh, M., A. Abdul-Kader, M. Khoder, A.R. Kalhout, 1999: In vitro propagation of semi-dwarfing cherry rootstock, Plant Cell Tiss Org, 59: 203-208.

- Brainerd, K.E., L.H. Fuchigami, 1981: Acclimatization of aseptically cultured apple plants to low relative humidity, J Am Soc Hortic Sci, 106: 515-510.

- Chikh, M., 2000: Etude de la multiplication du merisier (Prunus avium $\mathrm{L}$.) par semis après levée de dormance et par micropropagation à partir de drageons, MSc Thesis, ENSA (Ex. INA) Ecole Nationale Supérieure Agronomique.

- Cornu, D., 1990: Apport des techniques de culture in vitro dans les programmes d'amelioration de certaines especes forestieres. In: (eds.), Cinquantenaire de la culture in vitro, Versailles (FR), Les colloques de l'INRA 51 Ed. INRA, Paris.
- Debergh, P.C., L.J. Maene, 1981: A scheme for commercial propagation of ornamental plants by tissue culture, Sci HorticAmsterdam, 14: 335-345.

- Dolcet-Sanjuan, R., E. Claveria, R. Gruselle, A. Meier-Dinkel, C. Jay-Allemand, T. Gaspar, 2004: Practical factors controlling in vitro adventitious root formation from walnut shoot microcuttings, J Am Soc Hortic Sci, 129: 198-203.

- Douglas, G. C., 1999: Advanced and conventional methods for vegetative propagation of selected lines of oak and cherry, Kinsealy Research Centre Horticulture and Farm Forestry Series, No. 8., Dublin.

- Druart, P., P. Boxus, O. Liard, B. Delaite, 1981: La micropropagation du merisier à partir de la culture de méristème. In: (eds.) Proceedings of Colloque intern. sur la culture in vitro des essences forestières, IUFRO Section S2 015 meeting, 31 August-4 September 1981, 101-108 pp., Fontainebleau, France.

- Druart, P., 1992: In vitro culture and micropropagation of plum (Prunus sp.), Biotechnol Agric For, 18: 280-203.

- Durkovič, J., 2006: Rapid micropropagation of mature wild cherry, Biol Plantarum, 50: 733-736.

- Fotopoulos, S., T.E. Sotiropoulos, 2005: In vitro rooting of PR 204/84 rootstock (Prunus persica $\times$ P. amygdalus) as influenced by mineral concentration of the culture medium and exposure to darkness for a period, Agron Res, 3: 3-8.

- Fidanci, A., M. Burak, B. Erenoglu, M. E. Akçay, 2008: Determination of in vitro propagation techniques for some clonal cherry rootstocks, Acta Hortic, 795: 409-412.

- Garin, E., E. Grenier, G. Grenier-De March, 1997: Somatic embryogenesis in wild cherry (Prunus avium), Plant Cell Tissue Organ Cult, 48: 83-91.

- Gebhardt, K., 1985: Self rooted sour cherries in vitro: Auxin effects on rooting and isoperoxidases, Acta Hortic, 169: 341-349.

- Grant, N.J., N. Hammatt, 1999: Increased root and shoot production during micropropagation of cherry and apple rootstocks: Effect of subculture frequency, Tree Physiol, 19: 899-903.

- Grant, N.J., N. Hammatt, 2000: Adventitious shoot development from wild cherry (Prunus avium L.) leaves, New Forest, 20: 287295.

- Gruselle, R., C. Nicaise, P. Boxus, 1995: Regulation of in vitro shoot multiplication in Persian walnut by different carbon sources and by ammonium phosphate, Bull Rech Agron Gembloux, 30: 47-53.

- Hammatt, N., N.J. Grant, 1997: Micropropagation of mature British wild cherry, Plant Cell Tissue Organ Cult, 47: 103-110.

- Hammatt, N., 1999: Delayed flowering and reduced branching in micropropagated mature wild cherry (Prunus avium L.) compared with rooted cuttings and seedlings, Plant Cell Rep, 18: 478-484.

- Hammerschlag, F. A., R. Scorza, 1991: Field performance of micropropagated, own-rooted peach trees, J Am Soc Hortic Sci, 116: 1089-1091.

- Harrington, F.; G.C. Douglas, J. McNamara, 1994: Production of root suckers by mature clones of Prunus avium: Efficiency of root suckers and crown buds for culture initiation, Adv Hortic Sci, 8:11-14.

- Hazarika, B.N., 2003: Acclimatization of tissue-cultured plants, Current Sciences, 85: 1704-1712. 
- Ivanička, J., A. Pretova, 1986: Cherry (Prunus avium L.), Biotechnology in agriculture and forestry, Springer-Verlag, 154169 pp., Berlin.

- Kajba, D., J. Gračan, M. Ivanković, S. Bogdan, M. GradečkiPoštenjak, T. Littvay, I. Katičić, 2006: Očuvanje genofonda šumskih vrsta drveća u Hrvatskoj, Glas šum pokuse, Special edition, 5: 235-249.

- Kajba, D., I. Katičić, S. Bogdan, O. Tančeva Crmarić, 2012: Management, genetic gain and genetic diversity in clonal seed orchards in Croatia. In: (eds.): Proceedings Seed Orchards and Breeding Theory Conference, 21-25 May 2012, 42-44 pp., Antalya, Turkey.

- Kozai, T., Y. Iwanami, 1988: Effects of $\mathrm{CO}_{2}$ enrichment and sucrose concentration under high photon fluxes on plantlet growth of carnation (Dianthus caryophyllus L.) in tissue culture, J Jpn Soc Hortic Sci, 57: 279-288.

- Lloyd, G.B., L.B. McCown, 1981: Commercially feasible micropropagation of mountain laurel, Kalmia latifolia, by use of shoottip culture, Combined Proceedings of the International Plant Properties Society, 30: 421-427.

- Meier-Dinkel, A., 1986: In vitro Vermehrung ausgewählter genotypen der vogelkirsche (Prunus avium L.), Allg Forst Jagdztg, 157: 139-144.

- Mansseri-Lamrioui, A., A. Louerguioui, A. Abousalim, 2009: Effect of the medium culture on the micro cutting of material resulting from adult cuttings of wild cherry trees (Prunus avium L.) and of in vitro germination, Eur J Sci Res, 25: 345-352.

- Murashige, T., F. Skoog, 1962: A revised medium for rapid growth and bio assays with tobacco tissue cultures, Physiology of Plants, 15: 473-497.

- Osterc, G., Z. Luthar, F. Štampar F, 2004: The importance of the sterilization procedure for producing vigorous cherry plants (Prunus sp.) in vitro, Acta agriculturae slovenica, 83: 45-51.

- Pevalek-Kozlina, B., S. Jelaska, 1987: Microclonal propagation of Prunus avium L., Acta Hortic, 2: 599-601.

- Pevalek-Kozlina, B., C.H. Michler, S. Jelaska, 1994: Microclonal multilication of wild cherry (Prunus avium L.) from shoot tips and root sucker buds, Acta Bot Croat, 53: 52-62.

- Pijut, P.A., K.E. Woeste, G. Vengadesan, C.H. Michler, 2007: Technological advances in temperate hardwood tree improvement including breeding and molecular marker applications, In Vitro Cell Dev-P1, 43: 283-303.

- Pruski, K.W., T. Lewis, T. Astatkie, J. Nowak, 2000: Micropropagation of cokecherry and pincherry cultivars, Plant Cell Tissue Organ Cult, 63: 93-100.

- Quoirin, M., P. Lepoivre, 1977: Improved media for in vitro cultures of Prunus sp., Acta Hortic, 78: 437-442.

- Rifaud, J.L., D. Cornu, 1981: Utilisation de la culture in vitro pour la multiplication merisiers adultes (Prunus avium L.) sélectionnés en forêt, Agronomie, 1: 633-640.
- Rugini, E., 1984: In vitro propagation of some olive (Olea europaea sativa L.) cultivars with different root-ability, and medium development using analytical data from developing shoots and embryos, Sci Hortic-Amsterdam, 24:123-134.

- Ruzič, D., T.I. Vujovič, 2008: The effects of cytokinin types and their concentration on in vitro multiplication of sweet cherry cv. Lapins (Prunus avium L.), Hortscience, 35: 12-21.

- Ružić, D., M. Sarić, R. Cerović, L. Culafić, 2003: Contents of macroelements and growth of sweet cherry rootstock in vitro, Biol Plantarum, 47: 463-465.

- Santi, F., H. Muranty, J. Dufour, L.E. Paques, 1998: Genetic parameters and selection in a multisite wild cherry clonal test, Silvae Genet, 47: 61-67.

- Scaltsoyiannen, A., P. Tsoulpha, I. Iliev, K. Theriou, M. Tsaktsira, D. Mitras, C. Karanikas, S. Mahmout, V. Christopoulos, V. Scaltsoyiannes, D. Zaragotas, A. Tzouvara, 2009: Vegetative propagation of ornamental genotypes of Prunus avium L., Propag Ornam Plants, 9: 198-206.

- Sedlak, J., F. Paprstein, M. Erbenova, 2008: In vitro propagation of the P-HL dwarfing sweet cherry rootstocks, Acta Hortic, 795: 395-400.

- Szczygieł, K., T. Wojda, 2008: Mikrorozmnażanie czereśni ptasiej (Prunus avium L.) i jej plantacyjna uprawa we Włoszech, Leśne Prace Badawcze, 69: 72-75.

- Swietlik, D., S.S. Miller, 1983: The effects of paclobutrazol on growth and response to water stress of apple seedlings, J Am Soc Hortic Sci, 108: 1076-1080.

- Tančeva Crmarić, O., 2011: Mikrorazmnožavanje i genotipska raznolikost divlje trešnje (Prunus avium L.) u dijelu prirodne rasprostranjenosti u Hrvatskoj, PhD Thesis, Faculty of Forestry University of Zagreb.

- Tricoli, D.M., C.D. Mayard, A.P. Drew, 1985: Tissue culture of propagation trees of (Prunus serotina L.): Establishement, multiplication and rooting in vitro, For Sci, 31: 201-208.

- Vornam, B., K. Gebhardt, 1999: Application of CpDNA- and RAPD- markers in characterization of clone collections of wild cherries and performance of micropropagated plus trees, In: $S$. Espinel, E. Ritter (eds.), Proceed. Int. Congress „Applications of biotechnology to forest genetics”, 22-25 September 1999, Biofor-99, 61-71 pp., Vitoria-Gasteiz, Spain.

- Wainwright, H., J. Scrase, 1989: Influence of in vitro pre-conditioning with carbohydrates during the rooting of microcuttings on in vitro establishment, Sci Hortic-Amsterdam, 38: 261-267.

- Wardle, K., E.B. Dobbs, K.C. Short, 1983: In vitro acclimatization of aseptically cultured plantlets to humidity, J Am Soc Hortic Sci, 108: 386-389.

- Yang, H.Y., H. Schmidt, 1994: Einfluss verschiedener auxine auf die in vitro bewurzelung von süsskirschensorten (Prunus avium L.). Gartenbauwissenschaft, 59: 45-47.

- Zilkah, S., E. Faingersh, A. Rotbauta, 1992: In vitro propagation of three Nt $\times$ NI cherry rootstocks, Acta Hortic, 314: 93-97.

\section{Sažetak}

Velika pozornost pridaje se divljoj trešnji (Prunus avium L.) zbog plemenitog i visokovrijednog drva, ali i zbog važnosti očuvanja njezine genetičke raznolikosti. Oplemenjivanje divlje trešnje uobičajenim metodama uzgoja mogao bi biti vrlo spor proces, otežan time da je u prirodi teško dobiti redovne i dovoljne količine sjemena. Iako osnivanje klonskih sjemenskih plantaža osigurava redovitiji prinos kvalitetnog sjemena, ipak 
ostaje ovisnost od vremenskih prilika koje utječu na cvjetanje tj. prinos sjemena, kao i prisutne poteškoće kod klijavosti sjemena. Određene biotehnološke metode in vitro ubrzavaju proces i osiguravaju genetičku stabilnost. Najbrži i najkvalitetniji način oplemenjivanja divlje trešnje je mikroklonalna propagacija rejuveniliziranih jedinki, adultnih, elitnih genotipova s dobro razvijenim sustavom vlastitog korijena.

Optimalizacija procesa omogućava smanjivanje problema i troškove proizvodnje, a osigurano je i očuvanje aditivnih i neaditivnih sastavnica genetičke varijabilnosti. Dobivanje kvalitetnih sadnica s poznatim svojstvima, i to u vrlo kratkom vremenu, koristilo bi za osnivanje i nadopunu klonskih plantaža i za izravno pošumljavanje određenih površina ili popunjavanje šumskih sastojina elitnim genotipovima. Ex situ konzervacija, u klonskim plantažama, omogućava i očuvanje genetičke konstitucije bez promjena, ili s minimalnom mogućnošću promjena kroz mutacije, selekcije, driftom ili kontaminacijom sadnog materijala. Uvođenjem novih metoda očuvanja genetičkih resursa divlje trešnje, kao što su vegetativno razmnožavanje in vitro ili krioprezervacija, povećala bi se mogućnost kontrole genetičke stabilnosti, posebice genotipizacijom svakog klona.

Iz osnovane klonske sjemenske plantaže divlje trešnje, na području Šumarije Kutina, u proces proizvodnje in vitro uvedena su ukupno 24 genotipa (selekcioniranih plus stabala). Korištene su grančice $s$ formiranim pupovima u fazi dormancije, ali i tijekom porasta za uvođenje odabranog materijala u in vitro postupak i masovno vegetativno razmnožavanje. Ukupno su 23 klona uspješno uvedena u početnu kulturu. Uspostavljanju početne kulture najviše se opirao klon L3, koji jedini od 24 odabrana klona nije imao uspješnu dezinfekciju bez obzira što je više puta materijal uziman kroz različita godišnja doba. Tijekom ovih pokusa klon L3 nije uveden u početnoj kulturi.

Istražena je mogućnost optimalizacije rutinske metode mikrorazmnožavanja klonova po svim fazama. Utvrđene su aseptičke tehnike koje omogućuju uvođenje početne kulture kroz cijelu godinu (tablica 1). Utvrđeni su jedinstveni sastavi hranidbenih podloga (tablica 2) i kombinacija biljnih hormona (tablica 3) po fazama in vitro proizvodnje, što je rezultiralo dobivanjem kvalitetnih biljaka uz vrlo dobro preživljavanje tijekom procesa aklimatizacije. Za mikropropagaciju su korišteni BAP-1,0 mg/L, Kinetin-0,5 mg/L i IAA-0,5 $\mathrm{mg} / \mathrm{L}$, što je rezultiralo multiplikacijskom stopom 3-9 uz visinu biljaka 1,5-3,0 cm (slika 1). Zakorijenjivanje mikrobiljaka je postignuto kombinacijom IAA-2,0 mg/L, IBA-2,0 mg/L s dodatkom GA3-0,2 mg/L, te je potvrđeno da se kombinacijom regulatora rasta po svim fazama dobivaju kvalitetnije i veće biljke, uz vrlo dobro preživljavanje tijekom procesa aklimatizacije.

Na osnovi dosadašnjih istraživanja mikropropagacije divlje trešnje, u ovome je radu bio cilj istražiti mogućnost optimalizacije rutinske metode kulture tkiva za razmnožavanje klonova (plus stabala) divlje trešnje po svim fazama od početne kulture, mikrorazmnožavanja, izduživanja, zakorijenjivanja te aklimatizacije i dorade biljaka in vivo do komercijalne sadnice (slika 2).

KLJUČNE RIJEČI: in vitro razmnožavanje, plus stabla, klonska sjemenska plantaža, divlja trešnja 